\title{
INDSKRIFTEN PAA ODDENS MINDESTØTTE
}

\author{
Af Gustav Albeck
}

I

I en lille Afhandling „Grundtvig og Formkunsten“ (Tidsskrift udg. af Holger Begtrup, 1908, p. 129 ff.) peger Sigurd Müller med Rette paa den Ejendommelighed, at man allerede paa saa tidligt et Stadium i Grundtvigs Udvikling som i 1809 møder saa formfuldendt en Digtning som Versene paa Oddens Mindestøtte, „en Prøve, der saa stærkt som muligt godtgør, at ingen overgaar Grundtvig som Formkunstner, naar han er bedst - " (anf. Skr. p. 151). Müller giver ikke nogen sikker Forklaring paa det Forhold, at Grundtvig midt $\mathrm{i}$ en Periode, hvor Hovedparten af hans Lyrik var formløs og lidet velskabt, kunde skabe saa fuldendt et Mesterværk som Mindeverset over de Faldne fra Sjællands Odde. Han mener, at der er to mulige Forklaringer: enten at Digtet er „født $i$ et kort, beaandet Øjeblik, bleven til $i$ en Støbning, ikke "filet efter", kort sagt er, hvad man kalder en "genial Improvisation" " - eller at Digtet er "Frugten af lige saa megen Omhu som Geni“ (anf. Skr. p. 153). Ifølge sin Afhandlings These er Müller mest tilbøjelig til at antage den sidste Forklaring. Paa Grundlag af en fin Iagttagelse af Rytmeskiftet ved Overgangen til Inscriptionens femte Verslinje siger han, at „saa fint et Mesterværk ... finder man næppe uden at gøre noget alvorligt derfor" (anf. Skr. p. 15354). I det folgende understreger han, at "Grundtvig jo ingenlunde var bange for at gøre Rettelser, endogsaa ret indgribende Endringer i, hvad han havde skrevet. Dette fremgaar saa vel af efterladte Kladder, Udkast og andre Manuskripter af de forskellige Tryk, der findes af mange af hans Digte - Rettelser, hvoraf de fleste - i Modsætning til Oehlenslæger - er Forbedringer." (ibid.).

Müller er med andre Ord paa det rene med, at Haandskriftmaterialet muligvis kan yde ham Hjælp til Besvarelsen af hans Spørgsmaal. Det er derfor mærkeligt, at han ikke synes at være klar over, at man 


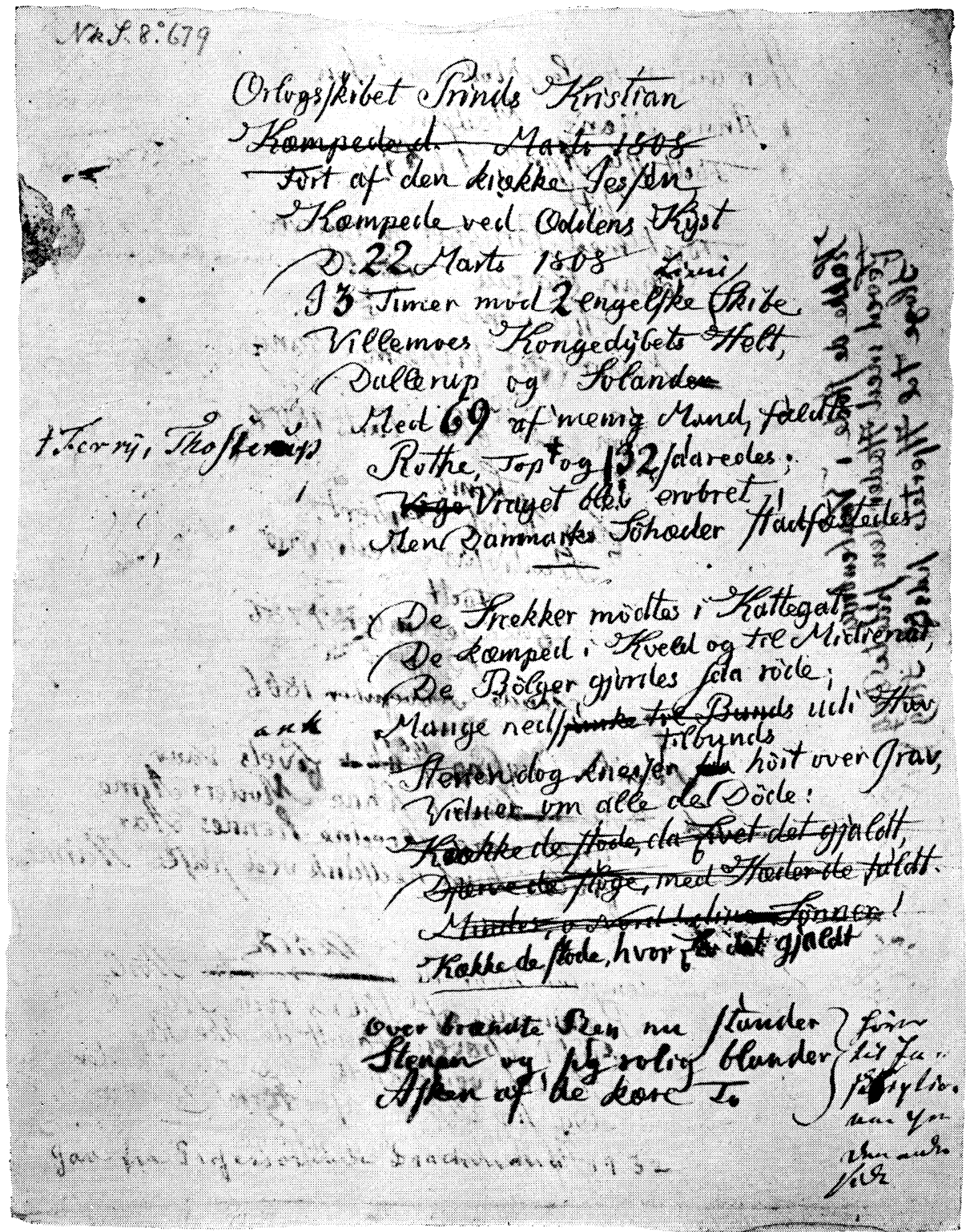

Grundtvigs første Udkast til Indskriften paa Oddens Mindestøtte.

Grundtvig fik, sandsynligvis umiddelbart efter sin Tilbagekomst til København (fra „Egeløkke“) i Maj 1808 Opfordring af sin fjerne Slægtning og Ungdomsbekendte, Kaptajn Lorentz Fribert, til at forfatte to Indskrifter. Den ene var til et Gravmæle, som L. Fribert vilde sætte over sin Moder og sin Broder, hvis Grave - efter Københavns Bombardement - blev flyttet fra Frue Kirkes Ruiner til Asisstens Kirkegaard. Den anden var til den Mindestøtte, som Fribert vilde rejse paa Odden. 


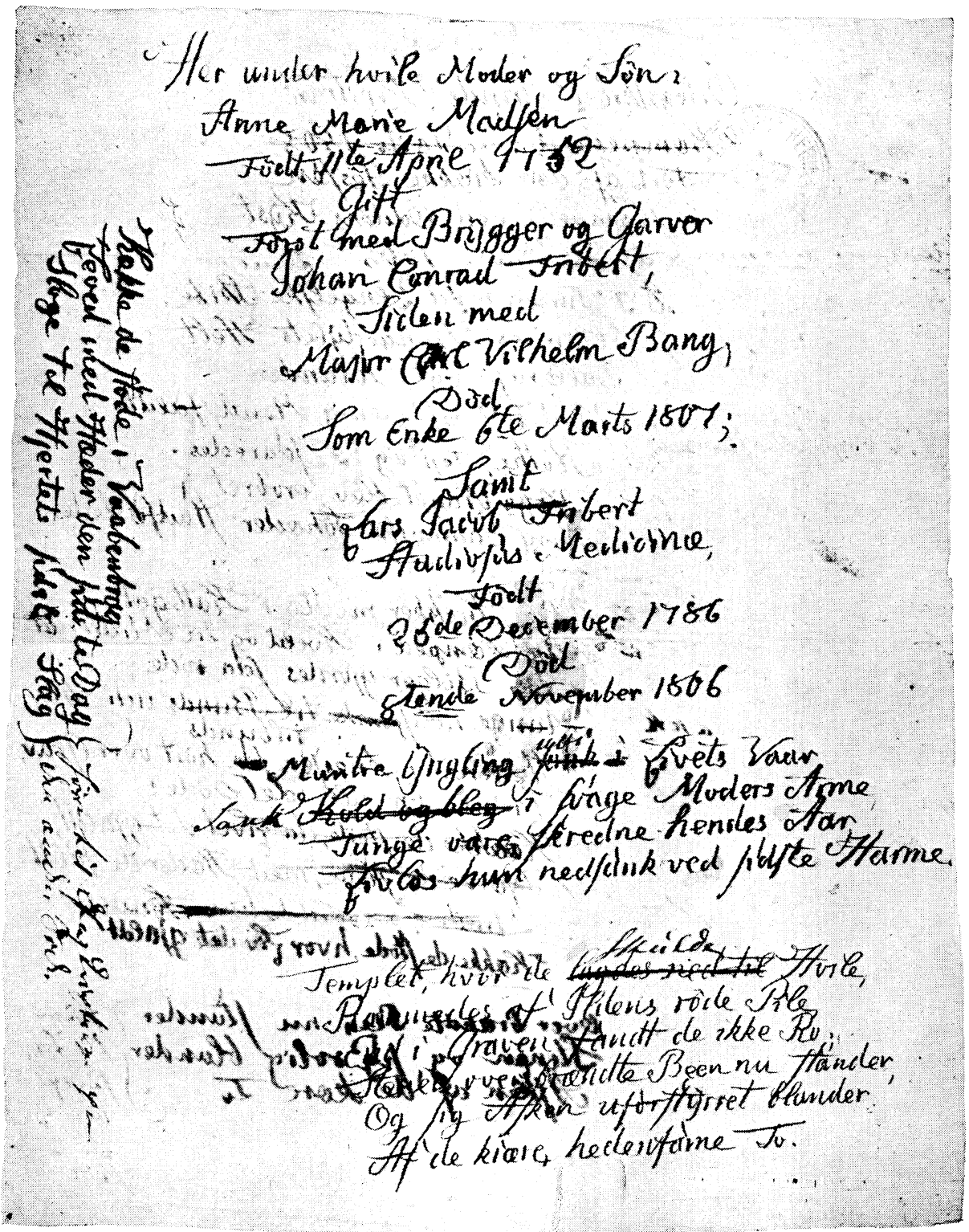

Den dobbelte Opfordring afspejler sig i det bevarede Kladdemateriale, som paa samme Blad (men paa hver sin Side) bringer Udkast til Indskriften paa Oddens Mindestøtte og til Familjegravstenen. Bemærk iøvrigt, at Gr. har nedskrevet Forslag til Rettelser i Familjegravstenens Tekst paa den Side, hvor Udkastet til Oddens Indskrift staar skrevet, og at omvendt Forslag til Rettelser i denne er opført paa den Side, der opr. bringer Familjegravstenens Tekst. Disse Rettelser er af Gr. indført paa rette Plads i en Tegning til Familjegravmælet, der øjensynlig har tjent som Korrektur for Stenhuggeren. (Se iøvrigt Steen Johansen Bibliografi Nr. 71 og Tavle II). 
netop med Hensyn til Indskriften paa Oddens Mindesten har et interessant Kladdemateriale, og dobbelt mærkeligt eftersom Holger Begtrup to Aar før Müllers Afhandling fremkom, offentliggjorde det vigtigste af dette Materiale i det Tidsskrift, hvori Müllers Afhandling senere blev trykt. ${ }^{1}$ )

Det fremgaar af en Sammenligning mellem Udkastet til Inscriptionen paa Oddens Mindesten og den endelige Tekst, at Grundtvig fuldstændig har omarbejdet sit oprindelige Udkast. Kladden frembyder saaledes et interessant Sammenligningsgrundlag til Brug for en æstetisk Analyse af den berømte Indskrift.

\section{II}

Den fulde Inscription paa Oddens Mindestøtte omfatter, foruden Stroferne, et indledende Prosastykke. Hvad dette angaar, frembyder Kladde og Tekst ingen Afvigelser af Interesse. Grundtvig har taget sig det let med Navnenes Bogstavering og fik i den Anledning paa Bøtten i „Politivennen" ${ }^{2}$ ). Prosastykket har øjensynlig ikke beskæftiget hans Tanker ret meget. Helt anderledes med Versene. Stiller man her Kladdens Strofe over for det senere saa berømte Digt, undres man over den vældige Afstand, der er imellem dem:

Kladde :

De Snekker mødtes i Kattegat

De kæmped i Kveld og til Midienat,

De Bølger gjordes saa røde

Mange nedsank tilbunds udi $\mathrm{Hav}^{3}$ )

Stenen dog kneiser (saa) høit over
Tekst :

De Snekker mødtes i Kveld ${ }^{4}$ ) paa

Hav

Og Luften begyndte at gløde

De leged alt over den aabne Grav

og Bølgerne giordes saa røde.

Grav,

1) Holger Begtrup : „To Indskrifter“, Tidsskrift, Kolding 1906, p. $177 \mathrm{ff}$. Se iøvrigt min Afhandling: „N. F. S. Grundtvigs Digtning om Peter Villemoes“, Fem danske Studier tilegnet Vilh. Andersen, 1934, p. 10-12, der bl. a. søger at godtgøre, at Grundtvig sandsynligvis allerede i Forsommeren 1808, kort efter sin Tilbagevenden til Hovedstaden, har faaet Opfordring til at forfatte Indskriften, og at de bevarede Kladder ( $\mathrm{Ny} \mathrm{kgl.} \mathrm{Saml.} \mathrm{679,} 8^{\circ}$.) er fra samme Aar. Derimod er den endelige Redaktion fra 1809.

$\left.{ }^{2}\right)$ Jfr. Begtrup „Tidsskrift“ 1906, p. 178, hvor ogsaa Grundtvigs noget arrogante Svar er aftrykt.

$\left.{ }^{3}\right)$ Linjen lød opr.: Mange nedsjunke til Bunds udi Hav, men sjunke til Bunds er overstreget, og i Marginen til venstre har en fremmed Haand skrevet sank.

$\left.{ }^{4}\right)$ I Kvædlinger, p. 152 : om Nat. 
Vidner om alle de Døde :

(Kække de stode, da Livet det gjaldt

Djærve de sloge, med Hæder de faldt

Mindes, o Nord! dine Sønner!)

Kække de stode, hvor Liv det gjaldt (Paa anden Side)

Kække de stode i Vaabenbrag

Leved med Hæder den sidste Dag

Sloge til Hjertets sidste Slag ${ }^{1}$ ).
Her er jeg sat til en Bautasteen At vidne for Slægter i Norden Danske de vare hvis møre Been Under mig smuldre i Jorden Danske af Tunge af $Æ t$ og af Id Thi skal de næunes i løbende Tid Fædrenes værdige Sønner.

Kladden virker trods det bevidst arkaiserende Ordvalg (Snekker, Kveld, Midienat) som konventionelt Bestillingsarbejde og udmærker sig ikke ved formalistiske Finesser. Den hæver sig kun i et enkelt Glimt over, hvad Grundtvig ellers præsterede af Lyrik i Tiden 0. 1808. Var dens Ordlyd blevet Stenens Inscription, vilde man næppe have husket den i Dag.

$\mathrm{Og}$ alligevel er det klart, at den endelige Tekst er arbejdet ud af Kladdens grove Ler. Herom vidner ikke blot Optakten: De Snekker mødtes, der er fælles for Kladde og Tekst, men først og fremmest Digtets Opbygning. Kladden giver os Digtets Motiv, Teksten Motivets Realisation.

Digtets Motiv falder i to Temaer, en episk Skildring (Slaget ved Odden) og Stenens hædrende Omtale af de Faldne. I Kladden er disse to Dele ikke nøje adskilte, men tværtimod forbundne - ikke blot saaledes, at Kladden savner Strofedeling (saaledes som Teksten har det), men ogsaa derigennem, at Slagskildringens sidste Linje forbindes med de følgende Ord om Stenen og dens Vidnesbyrd ved Hjælp af en gevaldig Antithese :

Mange nedsank tilbunds udi Hav,
Stenen dog kneiser høit over Grav,
Vidner om alle de Døde:
Kække de stode - osv.

I Realisationen er de synlige Baand mellem det indledende episke Stykke og Stenens Tale brudt, den forbindende Antithese er tilsløret. Resterne af den spores i Udtrykket den aabne Grav. De to Strofer er baade synligt og hørligt adskilte. Slagskildringen er fyldt med Bevægelse (som i Kladden) - medens 2. Strofe er statisk. I Kladden derimod er ogsaa anden Del af Verset fyldt med Handling og Bevægelse: Ste-

$\left.{ }^{1}\right)$ Parentheserne er overstregede Ord i Grundtvigs Kladde. De tre sidste Linier er Omdigtning, vistnok dikteret af Pladshensyn, da Grundtvig saa Tegningen til Monumentet; jfr. min Afhandling, N.F.S. Grundtvigs Digtning om Peter Villemoes, anf. Skr., p. 12. 
nen knejser, og i Lovprisningen af Heltene fornemmes endnu Drønet af Kanoner og Kartover.

Paa Forskellen mellem den indledende bevægelsesfyldte Strofe og Indskriftens rolige Tale beror det færdige Digts Virkning, en Virkning, der forstærkes - ikke blot ved den Pause, der markeres ved Strofeadskillelsen - men ogsaa rytmisk ved den chorjambiske Karakter, som det betonede $\mathrm{Her}$ giver Optakten til anden Strofe. Et lignende Rytmeskifte findes ganskevist ogsaa i Kladden:

De Bølger giordes saa røde

Mange nedsank tilbunds udi Hav -

men i dette Tilfælde er det umotiveret. Slagskildringen er ikke endt, og der tilstræbes ingen Pause eller Overgang. Hvad der i den endelige Redaktion fremtræder som et Middel til en bevidst kunstnerisk Virkning, fornemmes i Kladden som et generende Udslag af versificatorisk Ubehjælpsomhed.

\section{III}

Sammenligner man Tekstens Strofe 1 med de fire første Linjer af Kladden (der svarer dertil), falder det straks i Øjnene, at der er een af Verslinjerne, som omtrentlig gaar igen i Teksten, nemlig Kladdens Linje 3:

De Bølger gjordes saa røde -

som svarer til Tekstens Linje 4 :

Og Bølgerne giordes saa røde.

Udtrykket findes allerede i Grundtvigs første Villemoesdigtning, Villemoes, offentliggjort i Ny dansk Tilskuer, Nr. 43 og 44, den 26. Maj 1808. Strofe 5 i det paagældende Digt har følgende Skildring:

De Tidender fløi over Sø, over Land, At hisset i Nord vare Bølgerne røde, At Kristian kæmped og segned som Mand.

Men Villemoes faldt $\mathrm{i}$ det natlige Møde.

I denne Grundtvigs første Skildring af Slaget ved Odden anvender han saaledes et Udtryk, der gaar igen paa Indskriften i saavel Kladde som Tekst. Det voldsomme Billede af de blodfarvede Bølger har Lighed med tilsvarende Udtryksformer i latinsk Poesi og oldnordisk Skjalde- 
digtning, men er her muligvis influeret af et samtidigt dansk Digt. En vistnok meget yndet Sang af $P$. H. Haste, omhandlende Slaget paa Rheden, har en lignende Udtryksmaade som en Slags Mellemkvæde til alle Stroferne. Digtet offentliggjordes i Den danske Tilskuer, 15. Oktober 1801, Nr. 80, p. 633-34 og har Titelen: Takkesang ved een af anden Aprils Mindehøitider til dem, der offrede paa Fædrelandets Alter. Det hedder her bl. a. :

En Helteflok mod Britten stod,

De Bølger blev saa grusomt røde,

Dyrt solgte den sit kiække Blod,

Og tusend stolte Fiender døde;

Da heised Britten hvide Flag

Og bad om Roe paa Kampens Dag.

De tre følgende af Digtets ialt 5 Strofer har som anden Verslinje: De Bølger var saa grusomt røde. Det er et Omkvæd, som hamres ind i Læserens eller Tilhørernes Bevidsthed, saa dersom Grundtvig blot en enkelt Gang har læst eller hørt Sangen, tør man formode, at Linjen har fæstnet sig i hans Hukommelse. Noget Bevis for at Grundtvig har kendt Hastes Sang kan ikke føres, men det maa antages at være endog meget sandsynligt, at Grundtvig har stiftet Bekendtskab med den under sit Ophold paa Egeløkke ${ }^{1}$ ).

$\left.{ }^{1}\right)$ Haste var som Toldinspektør kommet til Assens i 1804. Den Tanke, at Poeten har været Gæst paa sydfynske Herregaarde, og at man der nu og da har sunget eller citeret hans Vise om den berømte 2. April er ret nærliggende. I sin Bog om Constance Leth (3. Udg. 1941, p. 70-71) fortæller Thyra Jensen om en Fest paa Enrum, hvor Constance Leths Søster, Fru Hedevig von Benzon reciterede Digtet og omtaler umiddelbart efter et Brev fra Hedevig til Constance, hvori en Anekdote fra 2. April berettes, og hvori ogsaa Villemoes omtales. Det ligger nær at antage, at samme Brev har fortalt om Festen paa Enrum, og at vi derigennem kunde faa et Bevis for, at Constance Leth havde kendt til Hastes Sang. Vejen laa da aaben for den Antagelse, at Linjen om de røde Bølger var naaet Grundtvig via den Tilbedtes Mund, hvilket kunde forklare hans Forkærlighed for Linjen.

En brevlig Henvendelse til Fru Thyra Jensen angaaende Kilden til hendes Beretning om Hedevig Benzons Recitation gav imidlertid den nedslaaende Oplysning, at Hovedparten af Brevmaterialet til Bogen om Constance Leth var gaaet op i Luer sammen med Fruens Originalmanuscript til Bogen om Constance Leth, just som den skulde i Trykken. (Fruen henviser i denne Forbindelse til sin Beretning: „Fra gamle Præstegaarde“ II, p. 148). Som Svar paa mit Spørgsmaal om, hvor Fruen havde læst om Fru Hedevigs Recitation, hedder det: „- - det har været $i$ et af de brændte Breve, som jeg levende har kunnet huske, da jeg paany skrev Bogen."

Det kan saaledes ikke med Sikkerhed fastslaas, at Constance har kendt 
I saa Fald giver en Sammenligning mellem Udtrykket hos Haste og hos Grundtvig et lille Indtryk af Grundtvigs Arbejde som Formkunstner.

At Hastes Ord grusomt er strøget, er ikke særligt bemærkelsesværdigt, eftersom selv svagere poetiske Begavelser maa kunne høre, at det - stik mod sin Hensigt - virker latterligt. Langt finere er Indsættelsen af det nye Verbum giordes, hvor Haste i første Strofe har blev, i de øvrige var, medens Grundtvig i Mindedigtet over Villemoes har var. Det er ikke Bølgerne, der er de grumme og fjendtlige, de er passive, receptive - tager Farve ved de Kæmpendes voldelige Færd. Men navnlig virker Verset gennem sin Lyd. Linjerne med giordes faar Purpurfarve af de mange mørke Vokaler. Helt vellykket bliver Verslinjen først $\mathrm{i}$ den endelige Redaktion, hvor det fremmedklingende „de Bølger" viger for den naturlige Bestemthedsform, og Linjen ved sit og sideordnes med 3 alvorsfulde og skæbnetunge Hovedsætninger, der giver Slagbeskrivelsen Ligevægt og Monumentalitet.

En af Grundtvigs fornemste Evner som lyrisk Digter er hans Evne til at starte et Digt med et fast Greb, der fører lige ind i Situationen eller Stemningen. Denne Færdighed træder her for første Gang frem i hans Digtning. Det er derfor ikke et Tilfælde, at saavel Kladde som Tekst starter med Ordene: De Snekker mødtes -, men medens Kladden lyder nøgternt oplysende som en Admiralitetsrapport:

De Snekker mødtes i Kattegat

De kæmped i Kveld og til Midienat

Mange nedsank tilbunds udi Hav -

stryger Teksten de præcise Steds-, Tids- (og Tabs-) Angivelser og fremkalder ved digterisk Omskrivning en billeddannende Virkning.

Udtrykket $i$ Kveld paa Hav, der erstatter den geografiske Betegnelse $i$ Kattegat giver Sceneriet Dybde og forlener det med Storhed. Man ser de store Fregatter som Silhouetter mod Aftenhimmelen og fornemmer det mørke Havs vældige Flade - og dets truende Dybde (den aabne Grav). Og ud af det dunkle Sceneri vokser Kampbilledet frem i glødende, røde Farver:

Hastes Sang, og man maa derfor være varsom med at formode, at Grundtvigs berømte Linje bunder $i$ et Kendskab, som hun har bibragt ham. Men det gaar vel an at pege paa Muligheden deraf.

Den danske Tilskuer fra 1801, hvori Sangen er trykt, findes i Følge venlig Meddelelse fra Greve W. Knuth ikke i Egeløkkes Bibliotek, men det kan tænkes, at Tidsskriftet har været der og er blevet udrangeret. Man kan derfor ikke se bort fra den Mulighed, at Grundtvig har læst Sangen. 
De Snekker mødtes i Kveld paa Hav

Og Luften begyndte at gløde

De leged alt over den aabne Grav

Og Bølgerne giordes saa røde.

Kampskildringen kunde minde om Jørgen Sorterup, som Grundtvig sandt nok berømmer og efterligner, men som han vistnok først har stiftet Bekendtskab med efter September 1810, da Rahbek udsendte sine historiske Mindesange (jf. min ovenf. citerede Afhandling om Grundtvigs Villemoesdigtning, p. $20 \mathrm{ff}$.). Da Grundtvig opgiver, at Teksten er skrevet 1809 - og da Mindesmærket blev taget i Øjesyn af Fr. VI d. 4. Marts 1810 og ifølge en Tradition i den fribertske Slægt blev indviet 22. Marts 1810, - er Tekstens Lighed med Sorterup øjensynlig tilfældig - eller rettere Følgen af et vist aandeligt Slægtskab, der saa meget lettere kommer til Udtryk, som Grundtvig her digter over et Emne, der har Lighed med de Motiver, der behersker de sorterupske Heltesange.

\section{IV}

Tekstens anden Strofe giver Mindestenens Monolog, den klare Forherligelse af alle de Døde. Ovenfor er der peget paa den Virkning, der fremkommer ved den tydelige Adskillelse mellem Slagskildringen og Stenens Tale og ved den chorjambiske Optakt til Strofe 2. Hertil kan føjes, at en væsentlig Del af Virkningen bestaar i den bratte Overgang fra 3. til 1. Person. Endnu i Kladden anvendes en omstændelig, anførende Sætning:

Stenen dog kneiser (saa) høit over Grav, Vidner om alle de Døde : -

I Teksten er hvert Spor af denne slettet. Men den „Besjæling“ af Stenen, som Kladden røber Tilløb til, kommer her fuldt til Udtryk. Stenen taler. I Grundtvigs 'Mindesang om Villemoes, sandsynligvis digtet Forsommeren 1808 - 0 : mellem Kladden og Teksten til Oddens Mindesten - hed det med Henblik paa det kommende Monument :

Over dine Kiæmpebeen

Reise vi en Bautasteen

Give Stenen Mæle.

I disse Vers ligger Kimen til Tekstens Strofe 2. Ordet Bautasteen findes ikke i Kladden, og først i Teksten har Stenen ret faaet Mæle. 
Men det er ogsaa værd at bemærke sig Forskellen mellem det Vidnesbyrd, Kladden lader Stenen aflægge, og Tekstens berømte Tale. I Kladdens oprindelige Form lød Stenens Hyldest til de Døde saaledes:

$$
\begin{aligned}
& \text { Kække de stode, da Livet det gjaldt } \\
& \text { Djærve de sloge, med Hæder de faldt } \\
& \text { Mindes, o Nord! dine Sønner! }
\end{aligned}
$$

Det er ikke beaandet Tale, kun net Almindelighed. Isolerede vilde man ikke kunne skelne disse Linjer fra saa meget andet af Samtidens Krigslyrik. Bedre blev det ikke, da Grundtvig af Hensyn til Pladsen paa Monumentets Tavle forkortede Linjerne ${ }^{1}$ ):

$$
\begin{aligned}
& \text { Kække de stode i Vaabenbrag } \\
& \text { Leved med Hæder den sidste Dag } \\
& \text { Sloge til Hjertets sidste Slag. }
\end{aligned}
$$

Da Grundtvig i 1809 skabte Stenens endelige Indskrift, var det fra Kladdens oprindelige Ordlyd han hentede sit Hyldestmotiv. Det er Slutningslinjen Mindes, o Nord! dine Sønner! der folder sig ud, gennemglødet af hans Inspiration:

$$
\begin{aligned}
& \text { Her er jeg sat til en Bautasteen } \\
& \text { At vidne for Slægter i Norden } \\
& \text { Danske de vare hvis møre Been } \\
& \text { Under mig smuldre i Jorden } \\
& \text { Danske af Tunge af } \text { Æt og af Id } \\
& \text { Thi skal de nævnes i løbende Tid } \\
& \text { Fædrenes værdige Sønner. }
\end{aligned}
$$

De almindelige, lidt fraseagtige Ord om Kækhed, Djærvhed og Vaabenbrag er strøget. Tilbage staar den Tanke, at Norden skal mindes sine Sønner. Og Begrundelsen er en ny. De Faldne er Danske.

Allerede Johannes Ewald havde i Fiskerne gjort Dansk til et Hædersnavn. I denne hædrende Betydning arvede Grundtvig - hvis Kendskab og Kærlighed til Ewalds Digtning var tidligt udviklet ${ }^{2}$ ) - Ordet Dansk fra det 18. Aarhundredes senere Skribenter. Det er Tonen fra „Fiskerne", som Grundtvig griber og forstærker. De Dyder, Ewald tillagde den danske Sømand, og som han sammenfattede i Ordet Dansk, havde ved de krigerske Hændelser faaet større Fylde. Det blev Grundtvigs Sag at give denne Udvidelse af Danskhedsbegrebet digterisk For-

1) Jf. min ovenfor anførte Afhandling, p. 12.

$\left.{ }^{2}\right)$ Se f. Eks. hans Reprimande til Oehlenschlæger 31/V 1804. Udv. Skr. I, p. 60 : „Den unge Digter gjør ei vel $i$ at nedsætte Evald - - -“ 
klaring. Han fyldte det, som det var hans Natur, med Fortid og Fremtid.

- I Stenens „Tale“ fornemmes ogsaa Mindelser fra Inscriptionen ved Thermopylæ. Fœdrenes vardige Sønner lyder som en Omskrivning af de berømte Ord om Kæmperne, der hviler, trofaste mod Lakedaimons Love. Ogsaa dèr taler Stenen direkte til Beskueren.

Grundtvig havde baade Kendskab og Kærlighed til Aanden fra Hellas, men iøvrigt var Thermopylæ et Ord, der dukkede op i adskillige Skriverier, da Danmark ved Aarhundredets Begyndelse efter lange Fredstider førtes i Krig. Saaledes foreslog A. K. Holm ${ }^{1}$ ) i Den danske Tilskuer 1801, Nr. 35 og 36, p. 280, at rejse Skærtorsdagsslagets Helte et Minde: „Steenen skal i faa Ord sige Efterverdenen, ikke Navne og Titler, ikke opdigtede Dyder, men at I faldt i standende Strid for Konge og Fødeland, at vi skjønnede Eders Daad og svore at ligne Eder. Den skal som Stenen over Thermopylas Helte sige Vandreren : „Gak hen! og forkynd Fædrenelandet, at vi ligge her, lydige dets Love." “

De faldne fra d. 2. April fik aldrig noget helt værdigt Minde. Først med Grundtvigs Inscription paa Oddens Mindesten fik Danmark sin Thermopylæ-Støtte, i hvis Tale klassisk Stil klinger sammen med en ny Tids profetiske Toner.

Udgangspunktet for denne Undersøgelse var det af Sigurd Müller rejste Spørgsmaal, om Stenens berømte Indskrift var en genial Inspiration eller „Frugten af lige saa megen Omhu som Geni“. Müller var som nævnt tilbøjelig til at antage det sidste, og vor Undersøgelse støtter i høj Grad hans These.

Selv var Grundtvig fuldt klar over, at han her havde skabt et værdifuldt Kunstværk. Han omtaler ret udførligt Friberts Arbejde for at faa Mindestøtten rejst (i Tillæg til Optrykket i Kvædlinger, p. 152-53) og fortsætter dernæst med at sige :

„Hvad nu disse Indskrifter ${ }^{2}$ ) angaae, da synes mig de have dog endeel af den Korthed og det Fynd som bør udmærke slige Støtters Tale - - - deres største Mangel er da vist, at Gud som stedse skulde ihukommes er $\mathrm{i}$ dem forglemt. Vist bleve de derved endnu et troere Billede af den Tid i hvilken de sattes og maaskee, desværre, et passe-

$\left.{ }^{1}\right)$ Andreas Krag Holm, der paa dette Tidspunkt var 2. resid. Kapellan v. Holmens Kirke og Præst v. Søkvæsthuset.

$\left.{ }^{2}\right)$ Flertalsformen skyldes, at Grundtvig ogsaa nævner den indledende prosaiske Del af Inscriptionen. 


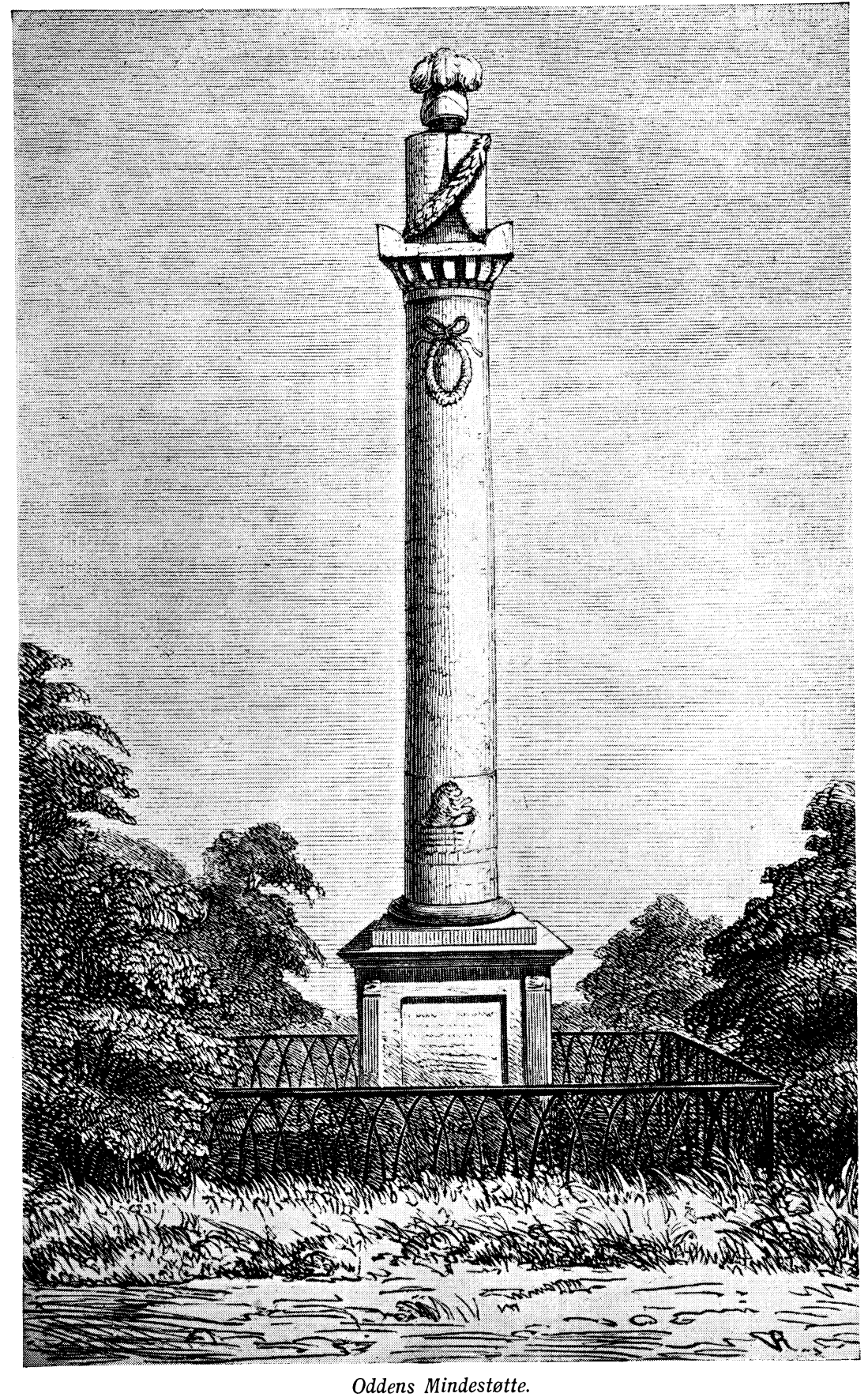

Efter lllustreret Tidende for 15. Juni 1862. 
ligere Eftermæle for endeel af de Faldne, men dermed er jeg ingenlunde undskyldt". I disse Ord fremtræder med megen Styrke den Konflikt mellem Digteren og Kristuskæmpen, der brød saa kraftigt frem ved Krisen i 1810. Det er Ytringer af denne Art, der har faaet mange til at tro, at Grundtvig lod haant om Formkunsten og blot bedømte et Digterværk efter Styrken af dets kristelige Forkyndelse. Der var Tider, hvor han viste Tilbøjelighed i den Retning, men man har gennem hele hans Liv Vidnesbyrd nok om hans Kamp for at finde den rette kunstneriske Form. Hans Arbejde med Oddens Indskrift, der faldt før Krisen 1810, er ikke noget isoleret, men et meget illustrerende Tilfælde ${ }^{1}$ ).

1) At Grundtvig ogsaa som ældre vedkendte sig Inscriptionen har vi Vidnesbyrd om. Saaledes reciterede han Digtet for sine Tilhørere ved Mands MindeForelæsningerne d. 11. Oktober 1838 (M.M. p. 332), ligesom han fremsagde det under Hjemrejsen fra Skamling 5. Juli 1844 (Udv. Skr. IX, p. 27). 